\title{
Effect of amiloride on metabolic alkalosis and hypokalaemia after cardiopulmonary bypass surgery
}

\author{
Margaret A. Hocking and W. H. Bain \\ From the Cardiovascular Surgical Unit, University Department of Surgery, Glasgow Royal Infirmary, Castle \\ Street, Glasgow
}

This study was undertaken to investigate the effects of the potassium-retaining diuretic, amiloride, on the potassium balance and on the alkalosis which occurs in patients after open-heart surgery.

Patients who had had valve replacement operations were divided randomly into two groups, one of which received $10 \mathrm{mg}$ amiloride daily in the postoperative period.

Patients who were given amiloride needed less potassium supplementation than those in the control group $(P<0.005)$ and yet maintained significantly higher plasma potassium levels $(P<0.05)$.

This small dose of amiloride also appeared to have some effect in reducing the alkalosis.

It is concluded that amiloride is a potentially useful drug after cardiac surgery.

Metabolic alkalosis and hypokalaemia are common after open-heart surgery. The former is thought to be due mainly to the transfusion of acid-citratedextrose blood, the citrate being metabolized to bicarbonate. It may also be partly due to hyperventilation (Bain et al., 1966; Grigor, I968). The hypokalaemia has been attributed to long-term diuretic therapy especially in patients who have valve replacement operations. This has been shown to lead to a depletion in the total body potassium despite a normal plasma level and oral potassium supplements (Mandal, Callaghan, and Sterns, 1968; Ebert, Jude, and Gaertner, 1965; Lockey et al., 1966). The copious diuresis which occurs as a part of postoperative management accentuates the hypokalaemia, and the importance of adequate potassium supplementation in this situation has been emphasized by several authors (Kettlewell, White, and Saunders, 1970; Breckenridge et al., 1972; Barnard et al., 1966; Shanahan, Anderson, and Morris, I969).

Amiloride is a mild oral diuretic which has potassium retaining properties (Martindale, 1972). Its exact mode of action is uncertain, but it is not a carbonic anhydrase inhibitor, nor an aldosterone antagonist (Baer et al., 1967). It appears to act on the distal tubular cells of the nephron, preventing the secretion of potassium, and enhancing the excretion of sodium and bicarbonate (Guignard and

Received 29 January 1974.
Peters, 1970; Baba et al., 1968; Bull and Laragh, 1968). It has been used both to correct the hypokalaemic alkalosis induced by the more powerful diuretics (Antcliffe et al., 1971) and in an attempt to conserve potassium before cardiac surgery (Singh, Hurley, and North, 1969).

This study was mounted to assess its value after cardiac surgery.

\section{Subjects and methods}

All patients who underwent valve replacement operations in this unit between I January 1973 and 3I July 1973 are included, except for those who had isolated aortic valve replacements who had not been taking diuretics before operation as it was found that they did not usually require postoperative diuretic therapy. Twenty-six patients were studied in all. They were divided into 3 groups, according to the number of valves they had had replaced. Within each group they were paired in chronological order and, using random number tables, one patient from each pair received Io mg amiloride daily from the third postoperative day onward. Amiloride is an oral preparation and could not be administered until oral feeding had been established. Fourteen patients acted as controls (C) and 12 received amiloride (A).

Twenty-four hour urine collections were made and arterial blood samples taken on the $3 \mathrm{rd}, 4$ th, 7 th, and 14th postoperative days. The urine was collected in bottles containing $50 \mathrm{ml}$ toluene, $0.5 \mathrm{~g}$ streptomycin, and $250 \mathrm{mg}$ chloramphenicol, and was kept refrigerated at $4^{\circ} \mathrm{C}$ until it could be analysed. Sodium, potassium, 
TABLE Details of patients included in study; until 3 rd postoperative day

\begin{tabular}{|c|c|c|c|c|c|c|c|c|c|c|c|c|}
\hline \multicolumn{3}{|c|}{$\begin{array}{c}\text { Control group } \\
C)\end{array}$} & \multirow[b]{2}{*}{ Operation } & \multicolumn{4}{|c|}{ Preoperative drug therapy } & \multicolumn{2}{|c|}{$\begin{array}{l}\text { Intra-operation and } \\
\text { until 3rd post-op. } \\
\text { day }\end{array}$} & \multicolumn{3}{|c|}{$\begin{array}{l}\text { Postoperative drugs } \\
\text { until day } 3 \text { (total dosage) }\end{array}$} \\
\hline $\begin{array}{l}\text { Case } \\
\text { No. }\end{array}$ & $\begin{array}{l}\mathrm{Age} \\
(y r)\end{array}$ & Sex & & $\begin{array}{l}\text { Diuretics } \\
\text { (mg/day) }\end{array}$ & $\begin{array}{l}\text { Potassium } \\
\text { supple- } \\
\text { ments } \\
(m E q \mid \\
\text { day }) \\
\end{array}$ & $\begin{array}{l}\text { Digoxin } \\
(m g)\end{array}$ & $\begin{array}{l}\text { Other } \\
\text { drugs }\end{array}$ & $\begin{array}{l}\begin{array}{l}\text { Volume } \\
\text { of blood }\end{array} \\
\text { trans- } \\
\text { fused } \\
\text { (units) } \\
\end{array}$ & $\begin{array}{l}\text { Sodium } \\
\text { bicar- } \\
\text { bonate } \\
(m E q)\end{array}$ & $\begin{array}{l}\text { Diuretics } \\
(m g)\end{array}$ & $\begin{array}{l}\text { Potassium } \\
\text { supple- } \\
\text { ments } \\
(m E q)\end{array}$ & $\begin{array}{l}\text { Digoxin } \\
(m g)\end{array}$ \\
\hline $\mathbf{I}$ & 54 & $\mathbf{M}$ & AVR & $\begin{array}{l}\text { Frusemide } \\
80\end{array}$ & 70 & - & Propranolol & 15 & - & $\begin{array}{l}\text { Frusemide } \\
80\end{array}$ & 270 & - \\
\hline 3 & 37 & $\mathbf{F}$ & $\begin{array}{l}\text { AVR } \\
\text { MVR }\end{array}$ & - & - & $\begin{array}{l}0.25 \\
\text { daily }\end{array}$ & Warfarin & 17 & 50 & $\begin{array}{l}\text { Frusemide } \\
20\end{array}$ & 214 & $1 \cdot 5$ \\
\hline 5 & 21 & $\mathbf{F}$ & MVR & - & - & $\begin{array}{l}0.25 \\
\text { b.d. }\end{array}$ & Warfarin & 9 & 60 & $\begin{array}{l}\text { Frusemide } \\
60\end{array}$ & 170 & 0.625 \\
\hline 8 & $5 \mathrm{I}$ & $\mathbf{F}$ & $\begin{array}{l}\text { MVR } \\
\text { TVR }\end{array}$ & $\begin{array}{l}\text { Frusemide } \\
40\end{array}$ & 24 & $\begin{array}{l}0.25 \\
\text { b.d. } \\
\text { ex. Sun. }\end{array}$ & Warfarin & 12 & - & $\begin{array}{l}\text { Frusemide } \\
80\end{array}$ & 324 & 0.5 \\
\hline 9 & 39 & $\mathbf{F}$ & MVR & Frusemide & 24 & $\begin{array}{l}0.25 \\
\text { daily }\end{array}$ & - & II & 150 & Frusemide & 280 & 0.25 \\
\hline 10 & 47 & $\mathbf{F}$ & $\begin{array}{l}\text { AVR } \\
\text { MVR }\end{array}$ & $\begin{array}{l}\text { Frusemide } \\
80\end{array}$ & 48 & $\begin{array}{l}0.25 \\
\text { b.d. }\end{array}$ & 一 & 13 & 100 & Frusemide & 130 & - \\
\hline 13 & $4 \mathrm{I}$ & $\mathbf{F}$ & $\begin{array}{l}\text { AVR } \\
\text { MVR } \\
\text { TVR }\end{array}$ & $\begin{array}{l}\text { Frusemide } \\
\quad 40\end{array}$ & 24 & $\begin{array}{l}0.25 \\
\text { b.d. }\end{array}$ & Bethanidine & 16 & 100 & $\begin{array}{l}\text { Frusemide } \\
200\end{array}$ & 225 & - \\
\hline 14 & 52 & $\mathbf{F}$ & MVR & $\begin{array}{l}\text { Frusemide } \\
40 \text { alt. dy }\end{array}$ & 24 & $\begin{array}{l}0.25 \\
\text { b.d. }\end{array}$ & - & 10 & 100 & 一 & 340 & $2 \cdot 25$ \\
\hline 15 & 33 & F & AVR & $\begin{array}{l}\text { Frusemide } \\
4_{40}\end{array}$ & 36 & - & - & I5 & 100 & Frusemide & 280 & 一 \\
\hline 18 & 29 & $\mathbf{M}$ & MVR & - & - & $\begin{array}{l}0.25 \\
\text { b.d. }\end{array}$ & - & 12 & 100 & $\begin{array}{l}\text { Frusemide } \\
\text { roo }\end{array}$ & 230 & 0.5 \\
\hline 22 & 44 & $\mathbf{F}$ & MVR & - & - & $\begin{array}{l}0.25 \text { ex. } \\
\text { Sat. and } \\
\text { Sun. }\end{array}$ & - & 6 & - & $\begin{array}{l}\text { Frusemide } \\
160\end{array}$ & 234 & - \\
\hline 23 & 46 & $\mathbf{F}$ & $\begin{array}{l}\text { MVR } \\
\text { TVR }\end{array}$ & Frusemide & 24 & $\begin{array}{l}0.25 \\
\text { b.d. }\end{array}$ & - & 12 & - & - & 340 & - \\
\hline 24 & 47 & $\mathbf{F}$ & MVR & $\begin{array}{l}\text { Frusemide } \\
80\end{array}$ & & & & & & & & \\
\hline & & & TVK & $\begin{array}{l}\text { ECA 100 } \\
\text { Spiro. } 100\end{array}$ & 24 & $\begin{array}{l}0.25 \\
\text { b.d. }\end{array}$ & - & 12 & 100 & $\begin{array}{l}\text { Frusemide } \\
80\end{array}$ & 280 & 0.5 \\
\hline 25 & 39 & $\mathbf{F}$ & MVR & $\begin{array}{l}\text { Bendro- } \\
\text { fluazide } \\
\text { Io }\end{array}$ & 16 & $\begin{array}{l}0.25 \\
\text { b.d. }\end{array}$ & - & II & - & $\begin{array}{l}\text { Frusemide } \\
\quad 40\end{array}$ & 310 & - \\
\hline
\end{tabular}

AVR = aortic valve replacement; $M V R=$ mitral valve replacement; $T V R=$ tricuspid valve replacement; $E C A=$ ethacrynic acid; Spiro. $=$ spironolactone.

chloride, and $\mathrm{pH}$ were measured on both blood and urine. In addition, titratable acidity and ammonia were estimated on the urine, and $\mathrm{PCO}_{2}$ and base excess on the blood. The sodium and potassium measurements were made with an EEL 27 integrating flame photometer and chloride using an Aminco solid state automatic chloride titrator. Ammonium was measured using Berthelot's method and a Unicam colorimeter. Blood gases were estimated on a Corning EEL $p \mathrm{H} /$ blood gas analyser 165, and urinary $p \mathrm{H}$ on a Radiometer $p \mathrm{H}$ meter 22.

Fluid balance was noted each day and frusemide and ethacrynic acid were administered as often as deemed necessary on clinical grounds to both groups. Potassium supplements were given if the plasma potassium, on routine daily measurement, fell below $3.9 \mathrm{mEq} / \mathrm{l}$. During the period of the study all patients ate a normal hospital diet, except 2 (one from each group) who were tube fed.

A few patients had their total exchangeable body potassium $\left(K_{E}\right)$ measured on days 3 and 17 . A known dose of radioactive ${ }^{43} \mathrm{~K}$ was given orally on day 2 , followed by a 24-hour urine collection, in which the radioactivity was counted by a Gammaguard 150 automatic gamma counter. A 'spot' specimen of urine was then obtained and this was both counted and analysed for total potassium. This procedure was repeated on day 16 . The calculation of $K_{E}$ was based on the formula first described by Corsa et al. (1950).

\section{Results}

Of the 14 control patients (C) 12 were women and 2 were men. In the amiloride group (A), 4 of the 12 patients were men. Two patients, one from each group, died during the study from unrelated causes.

The ages, preoperative drug therapy, total volume of blood transfused, total amount of sodium bicarbonate, and postoperative drug therapy until day 3, were compared in the two groups and the details are shown in the Table. The only significant 
TABLE (Cont'd)

\begin{tabular}{|c|c|c|c|c|c|c|c|c|c|c|c|c|}
\hline \multicolumn{4}{|c|}{$\begin{array}{l}\text { Amiloride group } \\
(A)\end{array}$} & \multicolumn{4}{|c|}{ Preoperative drug therapy } & \multicolumn{2}{|c|}{$\begin{array}{l}\text { Intra-operation and } \\
\text { until } 3 r d \text { post-op. } \\
\text { day }\end{array}$} & \multicolumn{3}{|c|}{$\begin{array}{l}\text { Postoperative drugs } \\
\text { until day } 3 \text { (total dosage) }\end{array}$} \\
\hline 2 & 44 & $\mathbf{F}$ & MVR & $\begin{array}{l}\text { Frusemide } \\
\quad 40\end{array}$ & 16 & $\begin{array}{l}0.25 \\
\text { daily }\end{array}$ & - & 9 & - & $\begin{array}{l}\text { Frusemide } \\
200\end{array}$ & 72 & 0.5 \\
\hline 4 & 47 & $\mathbf{F}$ & $\begin{array}{l}\text { AVR } \\
\text { MVR } \\
\text { TVR }\end{array}$ & $\begin{array}{l}\text { Frusemide } \\
\text { I } 20\end{array}$ & 48 & $\begin{array}{l}0.25 \\
\text { daily }\end{array}$ & - & 18 & - & $\begin{array}{l}\text { Frusemide } \\
60\end{array}$ & 258 & 0.25 \\
\hline 6 & 64 & $\mathbf{M}$ & AVR & $\begin{array}{l}\text { Frusemide } \\
40\end{array}$ & 24 & $\begin{array}{l}0.25 \\
\text { b.d. }\end{array}$ & 一 & 14 & 270 & $\begin{array}{l}\text { Frusemide } \\
\text { I } 40\end{array}$ & I00 & - \\
\hline 7 & 49 & F & $\begin{array}{l}\text { AVR } \\
\text { MVR }\end{array}$ & - & - & - & - & 16 & - & $\begin{array}{l}\text { Frusemide } \\
40\end{array}$ & 250 & - \\
\hline II & 36 & $M$ & $\begin{array}{l}\text { MVR } \\
\text { TVR }\end{array}$ & $\begin{array}{l}\text { Frusemide } \\
40 \text { alt. dy }\end{array}$ & 16 & $\begin{array}{l}0.375 \\
\text { daily }\end{array}$ & Dindevan & 17 & - & $\begin{array}{l}\text { Frusemide } \\
\quad 120\end{array}$ & 266 & 0.625 \\
\hline 12 & 50 & $M$ & MVR & $\begin{array}{l}\text { Frusemide } \\
40\end{array}$ & 16 & 0.25 & - & 14 & 120 & $\begin{array}{l}\text { Frusemide } \\
40\end{array}$ & 310 & 0.125 \\
\hline 16 & 49 & $\mathbf{F}$ & $\begin{array}{l}\text { Resuture } \\
\text { MVR }\end{array}$ & $\begin{array}{l}\text { Frusemide } \\
40\end{array}$ & I6 & $\begin{array}{l}0.25 \\
\text { daily }\end{array}$ & Warfarin & 16 & - & $\begin{array}{l}\text { Frusemide } \\
60\end{array}$ & 180 & $I \cdot 875$ \\
\hline 17 & 55 & $\mathbf{F}$ & MVR & $\begin{array}{l}\text { Aldactide } \\
25\end{array}$ & - & $\begin{array}{l}0.25 \\
\text { daily } \\
\text { ex. Sat. } \\
\text { and Sun. }\end{array}$ & - & 9 & 210 & $\begin{array}{l}\text { Frusemide } \\
60\end{array}$ & 310 & 0.75 \\
\hline 19 & 56 & $\mathbf{F}$ & $\begin{array}{l}\text { AVR } \\
\text { MVR }\end{array}$ & $\begin{array}{l}\text { Frusemide } \\
40 \text { Mon. } \\
\text { Wed. Fri. }\end{array}$ & $\begin{array}{l}8 \text { Tues. } \\
\text { Thurs. } \\
\text { Sat. }\end{array}$ & $\begin{array}{l}0.25 \\
\text { b.d. }\end{array}$ & - & 14 & 100 & $\begin{array}{l}\text { Frusemide } \\
360 \\
\text { ECA } 200\end{array}$ & 174 & 0.625 \\
\hline 20 & 48 & $\mathbf{M}$ & MVR & $\begin{array}{l}\text { Frusemide } \\
40\end{array}$ & 24 & $\begin{array}{l}0.25 \\
\text { tid }\end{array}$ & $\begin{array}{l}\text { Warfarin } \\
\text { Salbutamol }\end{array}$ & 15 & 200 & $\begin{array}{l}\text { Frusemide } \\
\quad 180\end{array}$ & 210 & 0.125 \\
\hline 21 & 49 & $\mathbf{F}$ & $\begin{array}{l}\text { AVR } \\
\text { M. valvot }\end{array}$ & $\begin{array}{l}\text { Bendro- } \\
\text { fluazide } \\
5.3 \mathrm{dy} / \mathrm{wk}\end{array}$ & $\begin{array}{l}\text { I6 } \\
3 \text { dys/ } \\
\text { wk }\end{array}$ & - & - & Io & 70 & $\begin{array}{l}\text { Frusemide } \\
\text { I } 40\end{array}$ & 195 & $I \cdot 125$ \\
\hline 26 & 49 & $\mathbf{F}$ & $\begin{array}{l}\text { AVR } \\
\text { MVR } \\
\text { Age }\end{array}$ & $\begin{array}{l}\text { Frusemide } \\
\quad 40\end{array}$ & 24 & $\begin{array}{l}0.25 \\
\text { daily }\end{array}$ & - & 9 & - & $\begin{array}{l}\text { Frusemide } \\
60\end{array}$ & 270 & 0.75 \\
\hline \multicolumn{3}{|c|}{ Group C means } & $4 I \cdot 43$ & $\begin{array}{c}\text { Frusemide } \\
34.29\end{array}$ & $22 \cdot 57$ & $\begin{array}{l}0.37 \\
\text { daily }\end{array}$ & & $12 \cdot 21$ & $6 I \cdot 43$ & $\begin{array}{c}\text { Frusemide } \\
72.86\end{array}$ & $276 \cdot 6$ & 0.4375 \\
\hline \multicolumn{3}{|c|}{ Group A means } & $49 \cdot 67$ & $\begin{array}{c}\text { Frusemide } \\
33.33\end{array}$ & $16 \cdot 5$ & $\begin{array}{l}0.275 \\
\text { daily }\end{array}$ & & 13.42 & $66 \cdot 67$ & $\begin{array}{c}\text { Frusemide } \\
121 \cdot 67\end{array}$ & $231 \cdot 25$ & 0.5625 \\
\hline $\mathbf{P}$ & & & $<0.02$ & $>0.5$ & $>0.5$ & $>0.2$ & & $>0.2$ & $>0.5$ & $>0.1$ & $>0.1$ & $>0.5$ \\
\hline
\end{tabular}

difference between them is that the mean age of the amiloride patients is higher than that of the controls.

In calculating the mean dose of diuretic, only frusemide was taken into consideration as this was the predominant diuretic used throughout. Though the difference is not significant, it should be noted that the amiloride group received, on average, $48.81 \mathrm{mg}$ more frusemide in the first two postoperative days than did the control group. One patient in this group was also given $100 \mathrm{mg}$ ethacrynic acid, which increases the difference between the groups. The specimens on day 3 were all obtained before any amiloride had been administered.

All the patients tolerated amiloride well and no side effects were seen.

\section{Effect of amiloride on the $\mathrm{PCO}_{2}, \mathrm{pH}$, and base} excess

Amiloride had no effect on the $\mathrm{PCO}_{2}$. The pattern of change in the base excess was not greatly affected by amiloride. Fig. $\mathrm{I}$ depicts the change in blood $p \mathrm{H}$. On days 4 and 14 the blood of the control group was significantly more alkaline than that of the amiloride group ( $\mathrm{P}<0.02$ and $\mathrm{P}<0.05$, respectively).

Effect of amiloride on the urinary $p H$, titratable acidity, ammonium, and hydrogen ion excretion

There was no statistically significant difference between the two groups with respect to any of these parameters. 


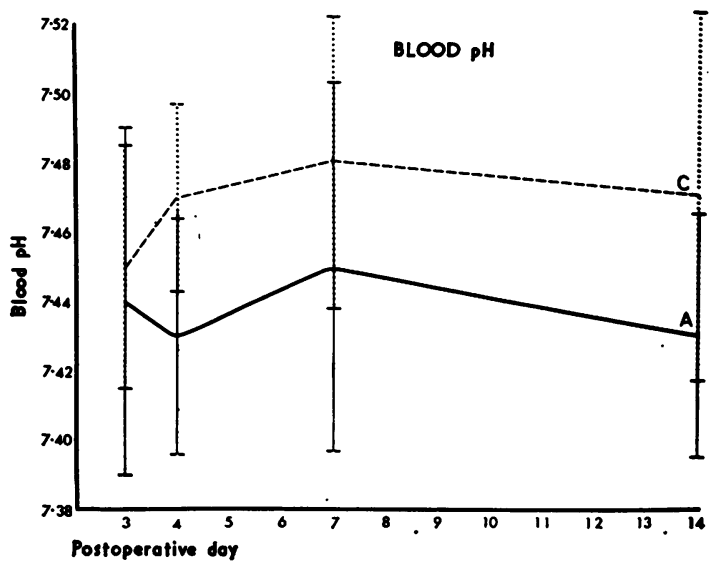

FIG. I Arterial $\mathrm{pH}$ ( + standard deviation) in the amiloride patients (A) and control patients (C).

The hydrogen ion excretion was calculated as the sum of the titratable acidity and ammonium excretion (Keele and Neil, I97I) and it fell slightly on days 4 and 7 .

Effect of amiloride on plasma and urinary sodium, potassium, and chloride

The plasma sodium in the control patients started at a slightly higher level than in the amiloride patients, and remained so throughout. This difference was not significant. The urinary sodium is shown in Fig. 2. The excretion of sodium was greater in the amiloride patients than in the controls on days 3,4 , and 7 , but was significantly so only on day $7(P<0.05)$. By day 14 the excretion was the same in both groups.

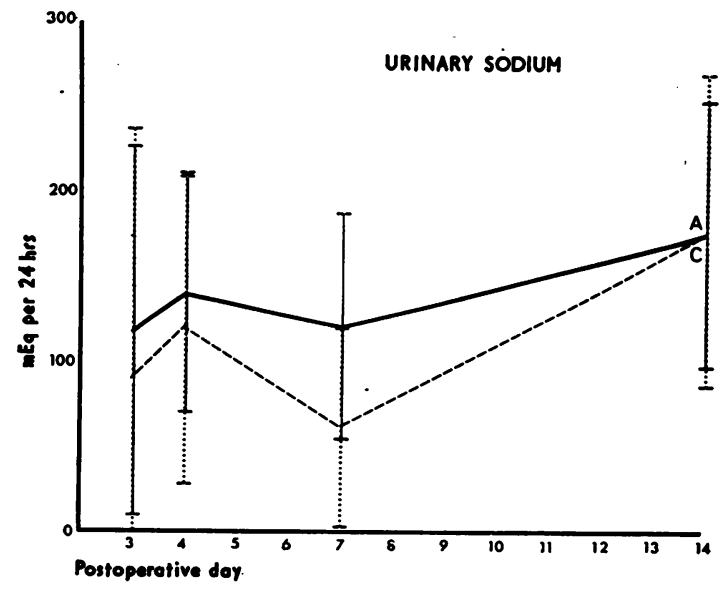

FIG. 2 Sodium excretion ( \pm standard deviation).

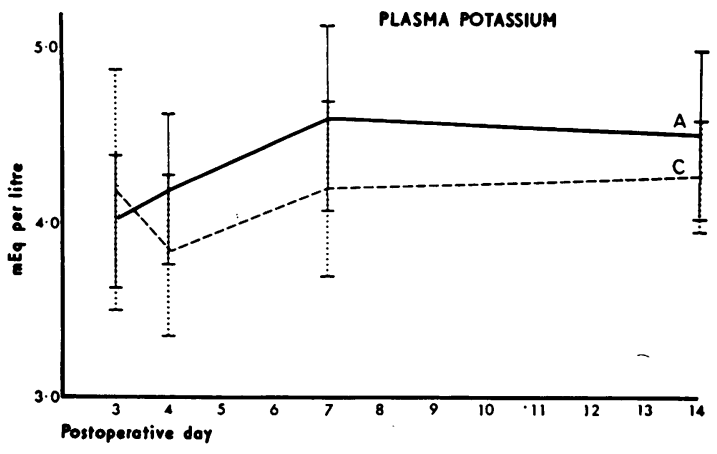

FIG. 3 Plasma potassium ( \pm standard deviation).

Plasma potassium was slightly lower on day 3 in the amiloride group, but on days 4,7 , and 14 it was higher than in the control group (Fig. 3). The difference was significant at the 0.05 level on days 4 and 7.

There was no significant difference between the urinary potassium in the two groups before amiloride was started on day 3. Subsequently, however, the amiloride patients excreted considerably less potassium than the controls $(P<0.02, P<0.01$, and $P<0.05$ on days 4,7 , and 14 , respectively) (Fig. 4).

A similar pattern was seen in the urinary sodium/ potassium ratio. The ratio was much greater in the

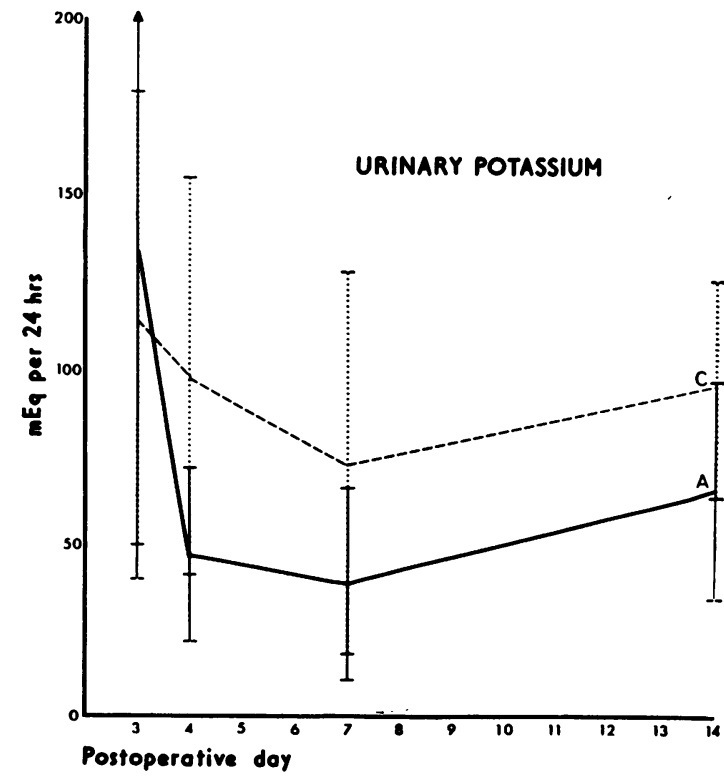

FIG. 4 Potassium excretion ( \pm standard deviation). 
amiloride group on days $7(\mathrm{P}<0.02)$ and $14(\mathrm{P}<$ $0.05)$.

No difference between the groups was seen with either plasma or urinary chloride.

\section{Effect of amiloride on fluid balance and drug therapy}

The fluid balance in the two groups was essentially the same. However, the patients given amiloride required less frusemide than the control group from day 8 onwards, the $P$ values being less than 0.05 on days, $8,9, \mathrm{II}$, and 13 , when frusemide alone is considered.

Fig. 5 shows the mean dose of potassium supplement required by the two groups. From day 5 onward the amiloride patients needed strikingly less potassium than did the control patients $(P<0.005$ on days 5 and 7 , and $P<0.001$ on day 6 and from day 8 to 14). This is much greater than would be accounted for by the difference in the dosage of frusemide.

There was no significant difference in the dose of digoxin received by the two groups.

\section{Effect of amiloride on total exchangeable body potassium}

No significant difference was found in the $K_{E}$ between patients who had received amiloride and those who did not, but the number of patients in whom the $\mathrm{K}_{\mathrm{E}}$ was measured was small. Singh et al. (1969) found little difference in the $K_{E}$ of their patients over a two-week period and concluded that this length of time was too short for a significant difference to occur.

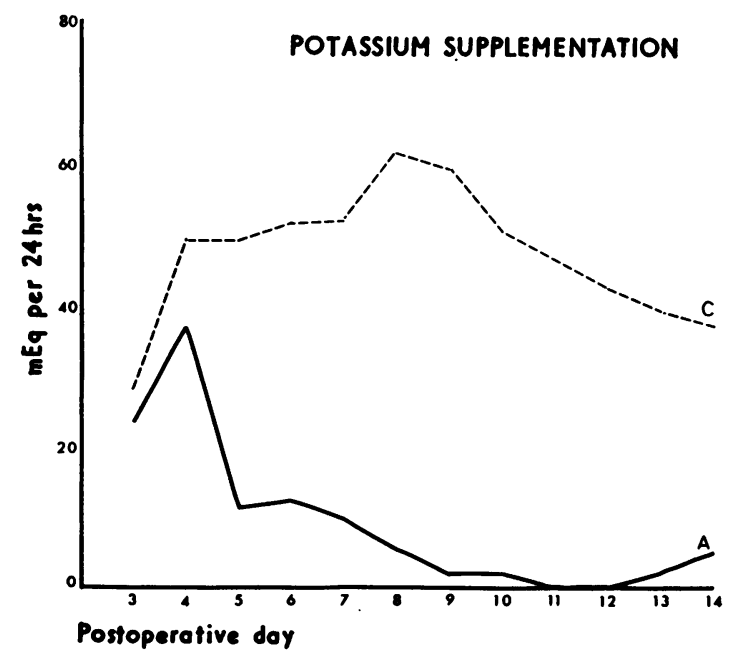

FIG. 5 Mean daily dose of potassium supplement.

\section{Discussion}

The mode of action of amiloride on the distal tubule of the kidney is uncertain. However, Guignard and Peters (1970) suggest that it prevents the excretion of potassium from the cells and also inhibits the uptake of sodium by acting on the luminal membrane causing it to become impermeable to these ions. This leads to retention of potassium and to a natriuresis. The excretion of hydrogen ions is simultaneously decreased because of the inactivity of the transport mechanism at the luminal border of the cell.

After open-heart surgery, though the patients are alkalotic, they excrete an acid urine. This may be attributed to the exchange of intracellular potassium for extracellular hydrogen and sodium ions. The potassium is excreted, leading to a depletion in the total body content of this ion (Jamieson and Kay, 1965). There is a higher concentration of hydrogen ion in the cell as a result of this interchange, and it has been postulated that it is the low intracellular $\mathrm{pH}$ of the tubular cells which is responsible for the secretion of an acid urine (Grigor, 1968; Adler, 197I).

Bull and Laragh (1968) showed that amiloride caused an increase in the excretion of bicarbonate in conjunction with the natriuresis (Baer et al., 1967).

In the situation described, amiloride would, therefore, be expected to lead to the following: a rise in plasma and total body potassium, with a fall in potassium excretion. Plasma sodium, blood $p \mathrm{H}$, and hydrogen ion excretion would fall and sodium excretion in the urine would rise.

A pronounced effect was seen on the potassium balance. The amiloride patients required much less potassium supplementation than did the control patients, and yet maintained their plasma potassium levels well above those of the controls. This was due to a significant decrease in the urinary excretion of potassium.

The plasma sodium of the amiloride group began and remained lower than that of the control group, but never significantly so. The lower value would be expected as a result of the natriuretic properties of amiloride. The increased excretion of sodium was confirmed on day 7 but it was the same in both groups on day 14. However, the sodium/potassium ratio in the urine was significantly different between the two groups on both days 7 and 14.

The blood $p \mathrm{H}$ became significantly lower in the amiloride patients. This indicates that amiloride does have an effect on the alkalosis. The decreased hydrogen ion excretion on days 4 and 7 is probably responsible for this. The $\mathrm{PCO}_{2}$ was little different between the two groups of patients. A larger dose of amiloride may well have a more 
significant effect on the alkalosis than the ro $\mathrm{mg}$ used here, the recommended dosage being Io to $40 \mathrm{mg}$ daily.

No patient in this series had a plasma potassium above the upper limit of normal.

It is unfortunate that, at present, no parenteral preparation of amiloride is available, since its use, intravenously, earlier in the postoperative period would offer even greater advantages.

\section{Conclusions}

From the results of this study, it appears that amiloride is a potentially useful drug after cardiac surgery, both from its action in decreasing the metabolic alkalosis, and in reducing the amount of potassium supplementation needed, while maintaining plasma potassium levels within normal limits.

We are grateful to Professor T. D. V. Lawrie, Dr. A. R. Lorimer, Dr. A. S. Rogen, and Dr. R. M. Thomson who referred the patients to our unit; to Dr. R. G. Bessent who helped with the ${ }^{43} \mathrm{~K}$ analyses; to Mrs. M. Russell for technical assistance; and to Dr. D. Robertson, Dr. T. Taylor, Dr. D. McLaren, and Dr. F. Williams for help and advice.

\section{References}

Adler, S. (1971). Cellular pH in potassium depletion. fournal of Laboratory and Clinical Medicine. 78, ro 3.

Antcliffe, A. C., Beevers, D. G., Hamilton, M., and Harpur, J. E. (1971). The use of amiloride hydrochloride in the correction of hypokalaemic alkalosis induced by diuretics. Postgraduate Medical fournal, 47, 644.

Baba, W. I., Lant, A. F., Smith, A. J., Townshend, M. M., and Wilson, G. M. (1968). Pharmacological effects in animals and normal human subjects of the diuretic amiloride hydrochloride (MK 870). Clinical Pharmacology and Therapeutics, 9, 318.

Baer, J. E., Jones, C. B., Spitzer, S. A., and Russo, H. F. (I967). The potassium-sparing and natriuretic activity of $\mathrm{N}$-amidino-3, 5-diamino-6-chloro-pyrazine-carboxamide hydrochloride dihydrate (amiloride hydrochloride). Fournal of Pharmacology and Experimental Therapeutics, 157, 472.

Bain, W. H., Nisbet, H. I. A., Forrester, A. C., and Mackey, W. A. (1966). Changes in haemodynamic and acid-base status after major cardiac surgery. In Wound Healing, p. I9I. Ed. by Charles Illingworth. Churchill, London.
Barnard, M. S., Saunders, S. J., Eales, L., and Barnard, C. N. (1966). Hypokalaemia during extra-corporeal circulation. Lancet, $\mathbf{1}, 240$.

Breckenridge, I. M., Deverall, P. B., Kirklin, J. W., and Digerness, S. B. (1972). Potassium intake and balance after open intra-cardiac operations. Fournal of Thoracic and Cardiovascular Surgery, 63, 305.

Bull, M. B., and Laragh, J. H. (1968). Amiloride. A potassiumsparing natriuretic agent. Circulation, 37, 45.

Corsa, L., Olney, J. M., Steenburg, R. W., Ball, M. R., and Moore, F. D. (1950). The measurement of exchangeable potassium in man by isotope dilution. Fournal of Clinical Investigation, 29, 1280.

Ebert, P. A., Jude, J. R., and Gaertner, R. A. (1965). Persistent hypokalemia following open-heart surgery. Circulation, 31, Suppl. I, 137.

Grigor, K. C. (1968). Metabolic alkalosis and acid urine following open-heart surgery with cardiopulmonary bypass. British fournal of Anaesthaesia, 40, 943.

Guignard, J. P., and Peters, G. (1970). Effects of triamterene and amiloride on urinary acidification and potassium excretion in the rat. European fournal of Pharmacology, 10, 255.

Jamieson, R. A., and Kay, A. W. (1965). Textbook of Surgical Physiology, and ed., p. 8o. Livingstone, Edinburgh and London.

Keele, C. A., and Neil, E. (1971). Samson Wright's Applied Physiology, 12th ed., p. 223. Oxford University Press, London.

Kettlewell, M., White, R., and Saunders, P. (1970). Potassium changes after open-heart surgery (abstract). British Heart fournal, 32, 557.

Lockey, E., Longmore, D. B., Ross, D. N., and Sturridge, M. F. (1966). Potassium and open-heart surgery. Lancet, I, 67I.

Mandal, A. K., Callaghan, J. C., and Sterns, L. P. (1968). Changes in intracellular potassium resulting from extracorporeal circulation. Surgical Forum, 19, 137.

Martindale (1972). The Extra Pharmacopoeia, 26th ed., p. 636. Ed. by N. W. Blacow. The Pharmaceutical Press, London.

Shanahan, E. A., Anderson, S. T., and Morris, K. N. (I969). The effect of modified pre-operative, intra-operative, and post-operative potassium supplementation on the incidence of post-operative ventricular arrhythmias. Fournal of Thoracic and Cardiovascular Surgery, 57, 413.

Singh, B. N., Hurley, P. J., and North, J. D. K. (I969). The use of amiloride in potassium depletion before cardiac surgery. American Heart fournal, 78, 22.

Requests for reprints to Dr. Margaret A. Hocking, Department of Surgery, Glasgow Royal Infirmary, Castle Street, Glasgow G4 oSF. 